\title{
The Role of the Game of Balanced Nutrition Ladder Snake in Influencing Changes in Knowledge and Attitudes of Children in Muhammadiyah Tanjung Morawa Elementary School
}

\author{
Oslida Martony \\ Politeknik Kesehatan Medan, Indonesia \\ Email: oslida64@gmail.com
}

\begin{abstract}
This study aims to determine the effect of the educational game of balanced nutrition ladder snakes on changes in knowledge and attitudes and actions in elementary school children in Muhammadyah school, Tanjung Morawa district. This type of research is a QuasiExperimental study (quasi-experimental design) with the design of One Group PretestPosttest. The sample in this study was 75 elementary school children Muhammadiyah Kec. Tanjung Morawa. Data was collected using a questionnaire that was filled in by the respondent himself. If the data is normally distributed then the type of test used is the dependent T-test (in pairs). If the data is not normally distributed then the test used is the ranking test. The statistical test results obtained $p$-value $=0,000<0.05$, which shows that the influence of snake ladder education game balanced nutrition to changes in knowledge and attitudes in school children. The conclusion in this study is the influence of the educational game of balanced nutrition ladder snakes on changes in knowledge and attitudes in school children.
\end{abstract}

Keywords: Snakes and Ladders Game, Balanced Nutrition, Knowledge, Attitude, Children.

\section{A. INTRODUCTION}

The problem of nutrition in Indonesia is increasingly complex, not only because of malnutrition, but the problem of excess nutrition and its consequences is increasing. Healthy lifestyle, including a balanced diet with nutrition, is one of the main factors in the complexity of nutrition problems in Indonesia. The school community is a group of people who have high potential to adapt messages of balanced health and nutrition, especially the elementary school community (Mulyani et al., 2014).

Based on the results of the 2013 Basic Health Research, it is known that the nutritional status of school-age children aged 6-12 years in Indonesia, namely the prevalence of very thin by $4.6 \%$ thin by $7.6 \%$, and fat by $9.2 \%$. Another problem often faced by school-age children in Indonesia is the low consumption of energy and protein below the minimum requirements, which is $44.4 \%$ and $30.6 \%$ (RI Ministry of Health, 2013).

Primary school children are one group that is prone to experiencing malnutrition among the causes is low economic level and unbalanced food intake and low parental 
knowledge. School children with a balanced diet tend to have good nutritional status (Anzarkusuma et al., 2014).

A balanced diet for school children is the fulfilment of nutrients such as carbohydrates, proteins, fats, vitamins and minerals from each food that they consume and following the portion of each age level in school children as it is known that a balanced diet in elementary school children is rarely fulfilled (Demitri et al., 2015). Fulfilment of nutrition in children often finds obstacles because many children who do not like to eat, do not want or are unable to eat so that the expectations in fulfilling nutrition that is harmonious, harmonious and balanced are not implemented (Mulyani, 2014).

Nutrition education is information about nutrition that can increase children's knowledge which is expected to change eating habits in children to a balanced diet (Supriasa, 2013). Efforts to overcome these problems are not enough just through the theory presented. Still, educational media are needed that play an essential role in making children better understand how to learn balanced nutrition to apply it in everyday life (Saputri et al., 2012).

Improving nutrition knowledge can be done with the right media, attractive, and easy to understand for children, the media can be in the form of educational games for children with traditional methods without a computer device into games that are easy, useful and fun is the essential key in designing the game. This concept refers to the concept of playing while learning (winarjaka 2013 in desi 2014).

Healthy education using this snake ladder educational game is useful for increasing knowledge about steps and attitudes in choosing healthy snacks. The results showed that health education using the educational game of snakes and ladders had a significant effect on increasing knowledge and attitudes in choosing healthy snacks for elementary school children (Saputri et al., 2012). Other research conducted shows that there are significant differences between the value of knowledge in balanced nutrition interventions using media, namely by measuring before and after (Bertalina, 2013). From the data obtained by observation and interviews show that the level of knowledge of children about nutrition, enough is $46.3 \%$ and $53.7 \%$ squaring knowledge. The attitude of children about positive nutrition $96.3 \%$ and negative $3.7 \%$, it is expected that providing nutrition education to improve student knowledge about balanced nutrition and healthy snacks or snacks (Maulana et al., 2013).

With the above information, then made a media that will be used, namely Snakes and ladders included in the visual learning media. Namely, media that can be seen with the sense of sight, this creates a pleasant atmosphere because several people play it. Snakes and ladders game is also one of the unique games. (Rizqi, 2015). The method of snake ladder media can influence the level of knowledge and supportive attitude, before and after giving material on the topic to be delivered. In this study, the 
effectiveness of snake ladder media is higher than the pictorial story media in perceiving knowledge, attitudes and actions (Hamdalan, 2013).

\section{B. LITERATURE REVIEW}

\section{Balanced Nutrition}

Balanced nutrition is the composition of daily food that contains nutrients in the type and amount that suits the needs of the body, taking into account the principle of diversity or variety of food, physical activity, cleanliness, and ideal body weight $(\mathrm{MOH}$, 2013). The Balanced Nutrition Principle consists of 4 (four) Pillars which are a series of efforts to balance between the nutrients that come out and the nutrients that come in by monitoring weight regularly (Ministry of Health, 2014).

According to the 2014 Ministry of Health, there are several explanations for the four pillars of balanced nutrition:

a. Eat a variety of foods

What is meant by diversity in this principle is in addition to the diversity of food types, including the proportion of balanced food, in sufficient quantities, not excessive and carried out regularly? The recommended diet in the last few decades has taken into account the proportions of each food group according to their needs.

b. Familiarize healthy behavior

By familiarizing the behaviour of clean living will prevent a person from exposure to the source of infection.

c. Doing physical activity

Physical activity which includes all kinds of bodily activities, including sports is one of the efforts to balance between expenditure and intake of critical nutrients in the body. Physical activity requires energy. Besides, physical activity also accelerates the metabolic system in the body, including the metabolism of nutrients. Therefore, physical activity plays a role in balancing nutrients that come from and into the body.

d. Monitor and maintain normal body weight

For adults, one indicator that shows that there has been a balance of nutrients in the body is the achievement of normal weight, i.e. Appropriate weight for height. This indicator is known as the Body Mass Index (BMI). Therefore, normal weight monitoring is something that must be part of the 'Lifestyle' with 'Balanced Nutrition', so that it can prevent the weight deviation from normal weight, and if there is a deviation, prevention and treatment can be taken immediately. For infants and toddlers, the indicator used in the development of body weight according to age. 


\section{Snakes and Ladders Game}

Snakes and ladders is a board game that is played by two or more people using dice and pawns as players. Creating conditions that are fun for children, and snakes and ladders game techniques can be developed to help children mastery of aspects of development (Raysia, 2016).

Snakes and ladders game can be made into an effective learning media because the exciting and straightforward nature of the game can make students enthusiastic in playing (Husna 2005 in ratnaningsih 2014). In this game, the picture of the ladder box snaps is replaced with a balanced nutritional picture.

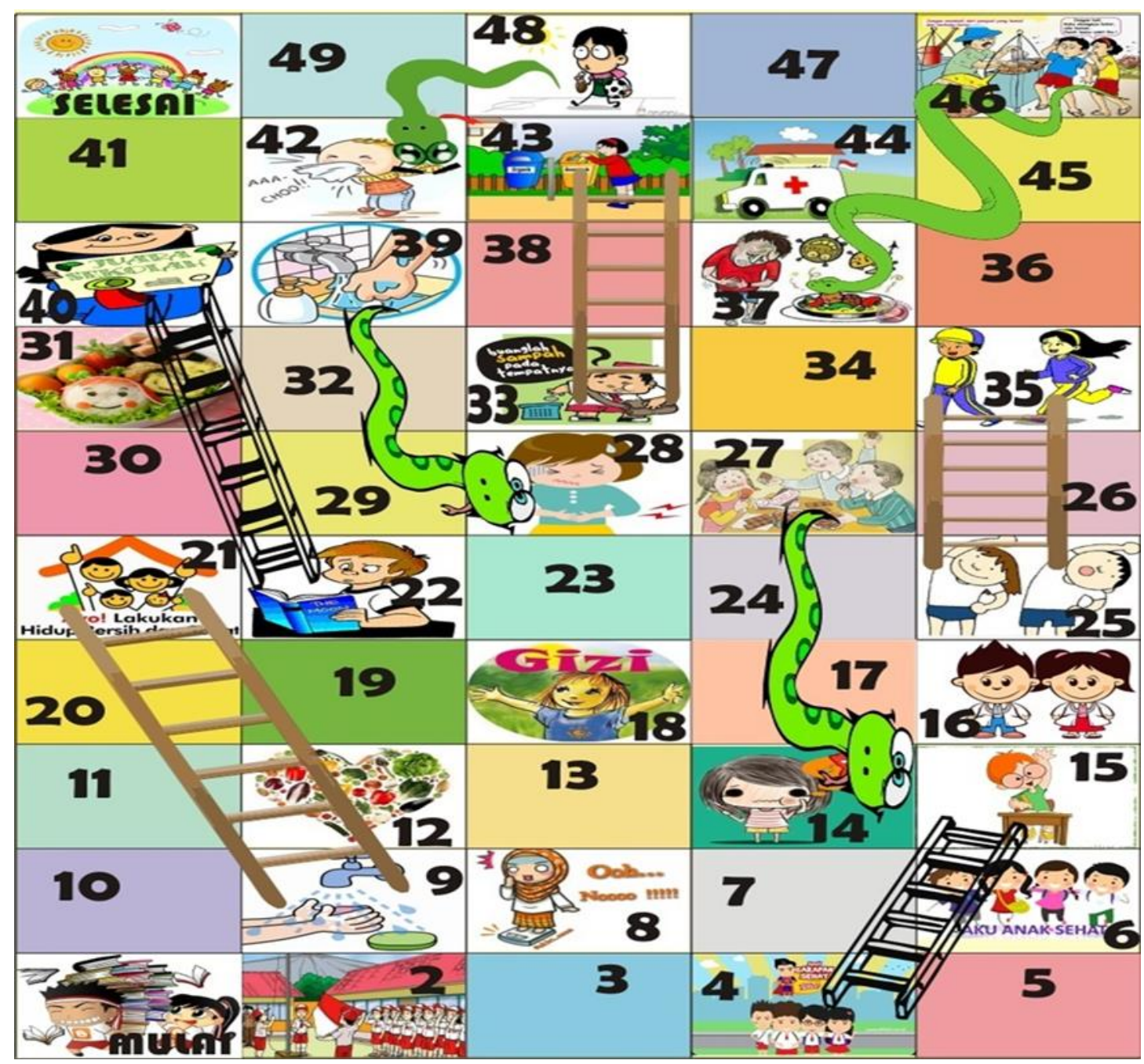

Figure 1 The Shape of a Balanced Nutrition Ladder Snake Game

The media for snakes and ladders in this research is a mat with a picture consisting of food based on balanced nutrition and a picture that illustrates the principles in the guidelines for balanced nutrition in a compartment, measuring $30 \times 30$ $\mathrm{cm}$ consisting of 50 plots, for dice size using cartons for forming the size dice measuring $20 \times 20 \mathrm{~cm}$. Each plot is given number 1 from the left corner of under to number 5 in the 
lower right corner, then from right to left starting at number 6 in the second row to number 10 , and setting it to number 0 .

Certain squares contain pictures that contain pictures and depict actions and behaviour. The message of good deeds will bring them up to a higher plot, while bad deeds will be punished by going down to the lower plot. Does each box have a question that will be answered by students and in the question there is a bonus for them to be able to answer the questions already listed

The game environment is done outside / the school field on a printed mat in the shape of a snake ladder then the players take turns playing snakes and ladders following the rules. The rules of the game are the game using dice and the game player from the first grid and take turns throwing the dice, take turns throwing the dice and walk according to the eyes of the dice that appear. In this game, the child mentions the questions received and answers the questions listed if the child can answer it will get a bonus for jumping a few boxes, but if the child cannot answer then the child will get a penalty that is down several cities, according to the rules listed in the question paper. This is done alternately with other children in one group. This game will stop when the child has reached the last plot, the finish tile. The images referred to on the snakes and ladders game mat in this study are pictures that illustrate the guidelines for balanced nutrition.

Increased knowledge and changes in children's attitudes toward messages conveyed by snakes and ladders games are children consuming a variety of foods, always washing hands, covering the food served, always covering the mouth and nose when sneezing, always using footwear, exercising, monitoring body weight.

\section{METHOD}

This type of research is a Quasi-Experimental study (quasi-experimental design) with the design of One Group Pretest - Posttest. (Notoadmojo, 2012). The design of this study is described as follows: agency.

\begin{tabular}{|c|c|}
\hline $\begin{array}{c}\text { Pre-test } \\
01\end{array}$ & $\begin{array}{cc}\text { Treatment } \longrightarrow & \text { Post-test } \\
(\mathrm{X}) & 02\end{array}$ \\
\hline
\end{tabular}

The sample in this study was 75 elementary school children Muhammadiyah Kec. Tanjung Morawa. Data was collected using a questionnaire that was filled in by the respondent himself. Based on the type of data, collected in this study include primary and secondary data. Primary data is data collected directly by the researcher consisting of Sample identity data, Data on nutritional status of samples; Knowledge and attitude data before and after the game. It is Secondary data, namely data obtained based on information collected by the school, which includes research and student data. 


\section{RESULT AND DISCUSSION}

\section{Overview of Sample Characteristics}

Based on the results of research that has been done, the data obtained by respondent characteristics based on the characteristics of genitals and age. The results of Univariate analysis in this study are presented in table 1 below.

Table 1 Distribution of Sample Characteristics

\begin{tabular}{llcc}
\hline \multirow{2}{*}{ No } & \multirow{2}{*}{ Sample Characteristics } & \multicolumn{2}{c}{ Analyst Result } \\
\cline { 3 - 4 } & & $\mathrm{n}$ & $(\%)$ \\
\hline Gender & Man & 37 & 49,3 \\
\hline & Woman & 38 & 50,7 \\
\hline \multicolumn{2}{l}{ Age } & & \\
\hline 7 years & 1 & 1,3 \\
\hline 8 years & 23 & 30,7 \\
\hline 9 years & 29 & 38,7 \\
\hline & 10 years & 21 & 28,0 \\
\hline & 11 years & 1 & 1,3 \\
\hline
\end{tabular}

Based on Table 1 above, it can be seen that there was a decrease in respondents based on gender characteristics at the time of the intervention, amounting to $49.3 \%$ for men and $50.7 \%$ for women. While based on the age characteristics, most respondents were 29 years old, which was $38.7 \%$.

Before conducting the hypothesis test that will be performed to see, there are differences in the average between the variables, the test requirements analysis is done first. To find out whether the population is normally distributed or not, the Kolmogorov Smirnof normality test is used.

The distribution is said to be normal if the sig value $>0.05$, then the parametric statistical test will be used. However, if the data is not normally distributed, that is, sig $<0.05$, the non-parametric statistical test is used.

\section{Bivariate Analysis Results}

The distribution of knowledge scores and attitudes before and after balanced nutrition can be seen in Table 2 below:

Table 2 Attitude Before and After Balanced Nutrition

\begin{tabular}{ccccccc}
\hline Variable & \multicolumn{3}{c}{ Before } & \multicolumn{3}{c}{ After } \\
\cline { 2 - 7 } & Min & Mean & Max & Min & Mean & Max \\
\hline Knowledge & 3,00 & 6,06 & 9,00 & 10,00 & 12,70 & 14,00 \\
\hline Attitude & 4,00 & 7,94 & 11,00 & 6,00 & 9,56 & 11,00 \\
\hline
\end{tabular}


Based on Table 2 above, it is known that the knowledge score before the intervention was 9.00 and after the intervention increased to 14.00. As for the attitude scores before and after the intervention also increased, each by 11.00 and after the intervention increased to 11.00 a fixed value.

\section{Knowledge of School Children before the intervention}

The knowledge tested in this study is knowledge about balanced nutrition messages. The balanced nutrition message delivered is not only emphasized on the consumption of diverse foods but is not only stipulated on the consumption of diverse foods but is also balanced with a clean lifestyle, physical activity, and regular weight monitoring the measurement of children's knowledge about children about balanced nutrition messages in this study conducted using tests. Nutritional knowledge of a person according to Ligga Nurul Lolana (2015) can be seen based on the respondent's answer to that given according to the questionnaire submitted.

The pre-test in this study was conducted to find out the basic knowledge of respondents about the balanced nutrition message. Based on the results of knowledge analysis during the pre-test conducted on respondents, both male and female respondents can be seen the percentage of students who can answer correctly some aspects of nutrition that are asked.

Based on the results of the analysis shows that the average score of knowledge scores of school children is low. The profound knowledge of students at the time of the pre-test is in line with Arimurti's research (2012) which shows that at the time of the pre-test the average knowledge score of the fourth and fifth-grade students at SD Mardi Yuana Depok was still in the low category of 31.69.

\section{Knowledge of School Children After Intervention}

Based on statistical tests conducted on average balanced nutritional knowledge shows an increase in knowledge scores after being given intervention in the form of a snake ladder media. Knowledge, according to Marisa (2014), is influenced by various factors, one of which is education. Education is one of the tools to produce changes in humans because human education will be able to know everything that is not or has not been known before. Education is defined as a process with specific methods so that people gain knowledge, understanding and ways of behaviour that are tailored to the needs. Nutrition education is needed to improve the nutrition knowledge of school children, forming positive attitudes towards nutritious food to form good eating habits.

\section{Attitudes of School Children}

Based on statistical tests conducted on the average attitude of school, children showed an increase in attitude scores after being given intervention in the form of a snake ladder media game. 
Attitudes are influenced by positive or negative feelings as a person's response to an object, person and environment, as a result of the knowledge and experience that has been obtained. The attitude itself has four levels, namely accepting, responding, respecting and being responsible.

\section{Effects of Snakes and Ladders Game on Knowledge and Attitudes of School Children}

Based on statistical tests conducted on average balanced nutritional knowledge shows an increase in knowledge and attitude scores after being given the intervention of the snakes and ladders game.

The main reason that led to an increase in knowledge and attitudes about balanced nutrition, according to Puspita (2012) was through the educational media used and the way of delivering educational material. Education media makes it easier for someone to understand information or materials that are considered complicated. In this case, the nutrition education media used are snakes and ladders games.

Increased knowledge and attitudes of respondents with the snake ladder game media method as much as five times face to face, and also explained the balanced nutrition material four times face to face.

\section{E. CONCLUSION}

The average knowledge score before the intervention is 6.06. The average knowledge score after the intervention increased to 12.70. In the min score of knowledge min, 3.00 becomes 9.00 and the max score before 9.00 becomes 14.00 . The average attitude score before the intervention is 7.94 . The average post-intervention attitude score increased to 9.56. In the min score, the min attitude of 4.00 becomes 6.00 and the max score before 11.00 becomes $11.00 \mathrm{H}$. The statistical test results obtained $\mathrm{p}$ value $=0,000<0.05$, which shows that the influence of the educational game of snakes and ladders balanced nutrition to changes in knowledge and attitudes in school children. Based on statistical tests, it is known that the average knowledge score before the intervention is 6.06 and after the intervention increases to 12.70. As for the average attitude scores before and after the intervention also increased, each by 7.94 and after the intervention increased to 9.56 .

\section{REFERENCES}

1. Arimurti, D. I. (2012). Pengaruh pemberian komik pendidikan gizi seimbang terhadap pengetahuan gizi siswa kelas v sdn sukasari 4 kota tangerang. Universitas Indonesia: Fakultas Kesehatan Masyarakat Departemen Gizi Kesehatan Masyarakat.

2. Anzarkusuma, I. S., Mulyani, E. Y., Jus'at, I., \& Angkasa, D. (2014). Status Gizi Berdasarkan Pola Makan Anak Sekolah Dasar Di Kecamatan Rajeg Tangerang 
(Nutritional Status Based On Primary School Student's Dietary Intake In Rajeg District Tangerang City). Indonesian Journal of Human Nutrition, 1(2), 135-148.

3. Bertalina, B. (2016). Pengaruh Promosi Kesehatan terhadap Peningkatan Pengetahuan tentang Gizi Seimbang pada Siswa Sekolah Dasar Negeri di Kecamatan Rajabasa Kota Bandar Lampung. Jurnal Kesehatan, 6(1).

4. Demitri, A., Nasution, E., \& Aritonang, E. Y. (2015). Pengaruh Pendidikan Gizi Tentang Pola Makan Seimbang Melalui Game Puzzle Terhadap Peningkatan Pengetahuan Anak SDN 067690 Kota Medan. Gizi, Kesehatan Reproduksi dan Epidemiologi, 1(2).

5. Desi, D., Hanim, D., \& Kusnandar, K. Pendidikan Gizi Melalui Permainan Model Ular Tangga Untuk Meningkatkan Kadar Hemoglobin Dan Konsumsi Protein Hewani Bagi Anak Taman Kanak-Kanak. Jurnal Gizi dan Kesehatan, 2(2), 101-113.

6. Hamdalan, A. (2013). Efektifitas Media Ceita Bergambar Dan Ular Tangga Dalam Pendidikan Kesehatan Gigi dan Mulut Siswa SDN 2 Petrang Kabupaten Jember. Jember; Fakultas Kesehatan Masyarakat Universitas Jember.

7. Hermawan, D. P. (2017). Efektivitas Penggunaan game edukasi berjenis puzzle, RPG dan Puzzle RPG sebagai sarana belajar matematika (Doctoral Dissertation, Institut Teknologi Sepuluh Nopember).

8. Karuniawaty, T. P., Sari, L. S., Wiweko, A., \& Karmila, I. (2020). Implementation of Educative Boardgame to Improve Knowledge, Attitude and Practice of Complementary Feeding in Stunting Locus at Central Lombok. American Journal of Pediatrics, 6(3), 172-181.

9. Lingga, N. L. (2015). Pengaruh Pemberian Media Animasi Terhadap Perubahan Pengetahuan dan Sikap Gizi Seimbang pada Siswa Kelas VI Sekolah Dasar Negeri Tanjung Duren Utara 01 Pagi Jakarta Barat. Program Studi Ilmu Gizi Fakultas Ilmu Kesehatan Universitas Esa Unggul Jakarta.

10. Ministry of Health of the Republic of Indonesia. (2013). Riset Kesehatan Dasar. Badan penelitian dan pengembangan Kesehatan Departemen Kesehatan Republik Indonesia. Jakarta: Depkes RI.

11. Ministry of Health of the Republic of Indonesia. (2014). Pedoman Gizi Seimbang. Departemen Kementrian Kesehatan Republik Indonesia. Jakarta: Depkes RI.

12. Nuryanto, M. (2014). Pengaruh Pendidikan Gizi Melalui Komik Gizi Seimbang Terhadap Pengetahuan Dan Sikap Pada Siswa SDN Bendungan di Semarang. Journal of Nutrition Collage,3(3), 925-932.

13. Maulana, L. O. A. D., Sirajuddin, S., \& Najamuddin, U. (2012). Gambaran Pengetahuan, Sikap dan Tindakan Terhadap Status Gizi Siswa SD INPRES 2 Pannampu. FKMUNHAS Makassar.

14. Mulyani, E. Y., Mustikawati, I. S., Handayani, P., \& Rumana, N. A. (2014). Pengetahuan, sikap, dan perilaku gizi seimbang anak sekolah dasar di SDN GU 12 Pagi. Jurnal Abdimas, 1(1), 98-104. 
15. Notoatmodjo, S. (2012). Promosi Kesehatan dan Perilaku Kesehatan. Jakarta: Rineka Cipta.

16. Prashanti, L. K. (2007). A study to determine the effectiveness of snake and ladder game on knowledge of common ailments' among primary school children of a selected school, Bangalore (Doctoral dissertation, RGUHS).

17. Puspita, I. D. (2012). Retensi Pengetahuan, Sikap, dan Perilaku Pasca Pelatihan Gizi Seimbang pada Siswa Kelas 5 dan 6 di Sekolah Dasar Terpilih Kota Depok (Doctoral dissertation, Tesis, Fak. Kesehatan Masyarakat, Universitas Indonesia, Depok).

18. Ratnaningsih, N. N. (2014). Penggunaan permainan ular tangga untuk meningkatkan motivasi belajar IPS kelas III A SDN Nogopuro, Sleman. Skripsi). Sekolah Sarjana, Universitas Negeri Yogyakarta, Yogyakarta.

19. Raysia, T. (2016). Penggunaan Media Permainan Ular Tangga Dalam Meningkatkan Kemampuan Berhitung Pada Anak Usia 5-6 Tahun di TK Tunas Melati Bandar Lampung. Fakultas Keguruan dan Ilmu Pendidikan Universitas Lampung Bandar Lampung.

20. Regulation of the Minister of Health of the Republic of Indonesia Number 41 of 2014 concerning Balanced Nutrition Guidelines.

21. Supriasa, I. D. N. (2013). Pendidikan dan Konsultasi Gizi. Jakarta: Buku Kedokteran EGC.

22. Rizqi, L. (2015). Penerapan media pembelajaran permainan ular tangga untuk meningkatkan penguasaan kosa kata bahasa arab siswa kelas IV MI Nurul Jadid Kolomayan Kab. Blitar (Doctoral dissertation, Universitas Islam Negeri Maulana Malik Ibrahim).

23. Saputri, L. O., \& Kristiawati, I. K. (2012). Peningkatan pengetahuan dan sikap dalam pemilihan jajanan sehat menggunakan alat permainan edukatif ular tangga. Skripsi: Universitas Airlangga. 